\title{
Development of handover concept in ICU/ICCU IBNU sina yarsi Islamic hospital bukittinggi
}

\begin{abstract}
Handover is professional responsibility diversion and accountability for some or all aspect of patients care or group of patients that can help to save patient. ICU/ICCU IbnuSinaYarsi Islamic Hospital Bukittinggi only have SPO draft, sohand over process and the factors that influencestill needed to in depth exploration to found various concepts that underlie hand over process. The purpose of this study is to develop patient handover concept. This research used qualitative method with grounded theory approach. This research has found a concept, which is "incompatibility in practice of patient handover effectively". From this study, hospital through nursing department should increase quality of nursing care especially patient safety related increase effectively communication through patient hand over activities and revise SPO draft based on the standards that should be applied in ICU and to authorized SPO of patient handover and socialized to the nurse.
\end{abstract}

Keywords: patient handover, communication, patient safety, hand off, shift changed
Volume 5 Issue 2 - 2018

Wiwit Febrina, Yati Afiyanti, Nelwati
Faculty of nursing, Universitas Andalas, Indonesia

Correspondence: Wiwit Febrina, Faculty of nursing, Universitas Andalas, Indonesia, Email wiwit.febrina@gmail.com

Received: July 20, 2017| Published: April 27, 2018

\section{Introduction}

Nursing Management is the implementation of nursing through staff nursing to give the care of nursing to patients. Management containing three the basic principles which characterize its main the efficiency in resource utilization, effective in choosing alternative activities to reach a goal organization, and rational in decision making managerial. The application of nursing management need the role of everyone involved in it for addressing the position through their management. ${ }^{1}$

The Function of management will lead nurse in achieving goals to the direction. According to Freeman \& Gilbert ${ }^{2}$ in Schlosser $^{3}$ there are several a key element in function nursing management of them that is planning, organizing, actuating (coordinating \& directing), staffing, leading, reporting, controlling and budgeting. Communication is part of the strategy coordinating (coordination which is valid in regulating services nursing. According to swansburg ${ }^{4}$ communication in professional nursing practice is a main element for nurse in implementing the care of nursing in a achieve optimum result so that the role of communication very important in the implementation of the nursing management. One of communication done nurses routine Nursing hand over accept the patients when exchange shift of nursing who was one of six goals of patient safety.

Effective communication, a timely, accurate, complete, clear, and acknowledged by resipien / of recipients will be reducing the errors, and produces increased patient safety. Alvarado et al. ${ }^{5}$ say the standard effective communication that is integrated with patient safety in Nursing hand over received patient and socialized thoroughly in nurses the executor of a will increase the effectiveness of and coordination. The effectiveness of can be increased by communicating important information raising continuity services for support patient safety.

Nursing hand over receives is Deep nurse communication Carry out nursing care In the patient. Rushton ${ }^{6}$ Say Nursing hand over the patient Designed as one method Relevant communication to the team Nurse every turn of shift, as Practice guide to provide information About the patients current condition, goals Treatment, treatment plan as well Determine service priorities. ${ }^{7-10}$ While Friesen Mention Nursing hand over received is Transfer of information (including Responsibility and accountability) During the transfer of care Sustainable opportunities About questions, clarifications and Confirmation of the patient. Nursing hand over will run smoothly if the nurses can do effective communicate. ${ }^{11-15}$

Preliminary study results at RSI Ibnu Sina Yarsi Bukittinggi during activity Residency, it was found that SOP of Nursing hand over the received is still in form draft SOP and apply in all of wards include ICU/ICCU. Besides the results of the interview with a nurse who responsible to nursing documentation saying draft of Nursing hand overs SOP in less Effective if applied in ICU/ICCU room, due to intensive space requires special attention including effective communication used when nursing hand over received. ${ }^{16-25}$

Based on the phenomena that has been explained and research that has been discussed earlier, can be inferred that the Nursing hand over-received activity is Effective must have reference for nurses to applying it so in the future this research develop the concept of nursing hand over Receive the patient in the inpatient room ICU/ ICCU by using Grounded theory approach. ${ }^{26-30}$

\section{Research methodology}

This study uses qualitative approach with Grounded theory method, by scientific approach on the meaning of ones experience which results in theory. The aim the use of grounded theory is to understand natural humans behavior by generalizing Theories about social phenomena and psychology. Important concept of research with approach grounded theory is no research starting from a theory however Based on data obtained when Research then the data formed into theory, then theory which have been obtained are connected with the discovery of data from previous research. ${ }^{31-42}$

\section{Research result}

The results of the data analysis process have been find the main concept of theory Grounded this is the "Application of Nursing hand over Accept patient is not up to standard". Which is supported by 
several themes The main being the main factor Affect the concept of Nursing hand over received In the ICU/ICCU ward. As for the themes that have been found are as follows: not optimal managerial function head of the room related activities nursing hand over the patient, implementation methods of nursing care not effective, deep barriers nursing hand over the patient receives as well risk of patient safety threat. ${ }^{43-57}$

\section{Discussion}

The first theme is not yet optimal the managerial function of the room head related nursing hand over the patient receives. The managerial function of the room head Is one of the main factors which underlies the application of nursing hand over accept patient is incompatible with standard. In this study $p$ is because it has not exposure to the head of the room with SOP of patient nursing hand over-in activities, So there is no guideline for head of nursing room in building staff nursing in doing nursing hand over the patient effectively. It is also due the transition process of the device that is on so nursing field makes nursing program plan the new can not be realized. ${ }^{58-62}$

The managerial function of the room head Very influential against Improvement of service quality Nursing. The room's head is The novice manager who is A nursing ace Given responsibility and authority In regulating and controlling Nursing care activities at Outpatient room. Head room straight away Dealing with patients, where In performing their duties Using a leadership style In implementing management functions Nursing to produce quality High nursing. ${ }^{7}$

The second theme is the implementation of the method A nursing care that has not effective. All this time based on mail Decision of director of hospital, method Nursing care used Is a team assignment method. However In its implementation, the team method It is still not optimal because Also related to the field program Nursing who plans to be Changing the method of nursing care Which will be used in the ward The ICU/ICCU ward becomes the case method.

Based on the literature review, the method More appropriate nursing care Used for intensive room Is a temporary case method Obtained from the results of this study Is a team method. The number Consideration of nursing field Against the application of the assignment method Such cases are caused Because of the limitations of human resources, nurse skills Which is still limited, as well as commitment The nurse itself is in execution The method is still lacking, Coupled with the lack of Knowledge of nurses related concepts Methods of nursing care. ${ }^{8}$

More nursing care methods Effective for the patient's character Treated in very intensive space Support in the application of methods Nursing care. other than that Nurses can provide care Nursing continues and comprehensive. Usually one person Nurses are responsible for One to two patients. Determination of methods of nursing care An inpatient room, on a regular basis Operations will affect The implementation of Nursing hand over the patient receives. In this case the role will be seen Each nurse at the time of the activity Nursing hand over the receipt. ${ }^{9}$

The method of nursing care that is Used in the implementation Greatly affect the activity Nursing hand over the patient. Method Nursing hand over the patient receives is Part of the Nursing hand over-in activities patient. Some categories are Support received
Nursing hand over method The patient is the nurse's place Do Nursing hand over receives patients and Data delivered by the nurse inside Nursing hand over the patient receipt. Based on the results of the study, nurses In the ICU/ICCU ward Usually Nursing hand over the receipt The first patient once opened by Head room at the bellboy and after that Ka. The team reported all that Associated with the patient in front of the board Action resumed by running Together towards the bed each- Each patient.

Based on literature review Implementation of bedside handover will More effective if applied in space Intensive with consideration Shorten the execution time Nursing hand over received, patient observation can Done directly so Patients are not neglected. other than that Bedside handover is also very Have an impact on improvement Patient safety. For critical patients Or labile, reports on the side of the premises Patient sleep provides an opportunity Nurses to observe patients in a manner Together, solving problems on a regular basis Together, clarify issues, Discuss, and guarantee Continuity of care within Efforts to reduce errors and Improve patient's safety at the time Nursing hand over receipt activities.

The second category supports The patient's Nursing hand overing method is Data delivered during the activity Nursing hand over the patient is still diverse And not yet structured. Based on Research results, data submitted Nurse when Nursing hand over the receipt The patient includes the doctor's advise against Patients and care plans Nursing, actions already and Which will be done by nurse shift next. Every nurse inside Convey it differently and Still not well structured.

In line with the principle of communication Effective above, Nursalam ${ }^{10}$ Divide the Nursing hand over-in activities Into several stages of the stage Preparation, implementation stage, and PostNursing hand over-receive stage. When Preparation stage there are some activities Done, this stage is done at Nurse station. The nurse will Do Nursing hand over receipt is Nurse executor. The next step Is the stage of Nursing hand overing Receive, place settings on stage Implementation there are two places, that is Nurse station and treatment room. The executor of this stage is the head Room, nurse executive. Stage The last Nursing hand over of the receipt is PostNursing hand over-receive stage, the place Used is nurse station While executing from this stage Is the head of the room and nurse Executor.

According to Jefferson ${ }^{11}$ in Do Nursing hand over there accept The development of alternative communication Effective that can be done that is SBAR method with consideration SBAR communication can save Time so that the nurse will The agency may take immediate action Especially against critical patients such as In intensive space. ${ }^{6,12,13}$

SBAR communication is Communications are carried out in a manner Face to face consisting of 4 Component ie $\mathrm{S}$ (Situation): Is a picture that Happened at that time. B (Background): Is something that lay The situation is happening. A (Assessment): is a Assessment of a problem. $\mathrm{R}$ (Recommendation): is a Actions where asking for advice to The right action should be Done for the problem.

Furthermore the inner constraint factor Nursing hand over the patient receipt Is a possible cause Making the activities Nursing hand over Ineffective patients. This matter Caused by troubleshooting The unfinished can Affect the smoothness of the process Nursing hand over accept activities for example Nurses who were absent during the activity Nursing hand over the receipt, the nurse does not Concerned with receiving Nursing hand over activities, As well as non-followers 
Nursing hand over it completely so Can not meet the needs Their patients at the time.

Hughes in Kamil ${ }^{15}$ Outlining some issues and Obstacles in the implementation of Nursing hand over Accept patient. The main thing is Communication, effective communication Is a technique that must be mastered By every nurse. Ability Communication will be able to influence Delivery and acceptance Optimal for nurses to be on duty. Fatigue can also be an obstacle In patient Nursing hand overing activities. Fatigue is usually caused The high workload of the nurse so No more focus in doing Nursing hand over the patient. For the nurse Beginner, must be supported with More additional information Specific.

Indicator of nursing service Quality can be achieved with Carry out various ways Available one of which is Nursing hand over the patient. Positive impact Which can be taken from execution Nursing hand over the receipt of the patient Is to ensure safety Patient so nurses can Provide maximum service Against the patient.

The application of Nursing hand over received patients is not According to the standard is the core of Findings of this study that can Risk to safety threats patient. Nursing hand over the patient Is one of six The patient's safety goals are Implementation of effective communication.

The results of this study are also in accordance with Research conducted by Arora \& Johnson ${ }^{17}$ that the procedure Nursing hand over in effectively within Improve sustainability, quality As well as safety in giving Service to the patient. Research Related also done by Adams \& Osborne ${ }^{18}$ on the Central Coast California District Hospital Stated that the current communication Nursing hand over the receipts between nurses Is very important So it can anticipate danger Patient safety at the hospital.

Alvarado et al..$^{5}$ says The existence of effective communication standards Integrated with patient safety In receipt of patient and Socialized as a whole On the implementing nurse will Improve effectiveness and Coordination in communicating So important information Improve sustainability Service in support Patient safety. ${ }^{63}$

Ineffective communication can Threatening patient's safety at hospital. Alvarado et al. ${ }^{5}$ Said inaccurate information Can cause that impact Serious in patients, almost $70 \%$ Sentinel event is the incident Resulting in death or injury The serious in the hospital caused Because of poor communication. Reese ${ }^{19}$ states that communication Is an important part in Implementation of service, communication Which support no safety Regardless of standards and procedures Communication used and aspects Informed safety. The results of data review on the existence Unexpected events, events Almost injured as well as the incident Resulting in disability and death The main cause is Inaccurate communication moment Nursing hand over the patient.

Gaps in communication when Handover or intermediate patient intermediate Units of service, and within and Between service teams, can Resulting in disconnection Service continuity, treatment Which is not appropriate, and potential can be Resulting in injury to the patient. Recommendations intended for Improve patient handover pattern Including the use of protocols for Communicating that information Critical; providing opportunity For practitioners to ask and Ask questions At the time of patient handover.

\section{Summary}

Development of Nursing hand over-received concept Patients in ICU/ICCU inpatient wards RSI Ibnu Sina Yarsi Bukittinggi has Produce a core theme ie The application of Nursing hand overing received patients is not according to the standard. Factor-fakor Which affects discrepancies It is not yet optimal The managerial function of the room head Related Nursing hand over the patient receives, Implementation of care methods Ineffective nursing, Obstacles in the implementation of Nursing hand over Accept patient. Core themes are The resulting can have an impact Against the risk of safety threats patient.

\section{Suggestion}

Expected to further improve Program related strategic plan. The implementation of patient Nursing hand over receipt, Analyze the power needs Nursing in applying Methods of nursing care in space Especially intensive room, ${ }^{60}$ Improve related socialization The implementation of the Nursing hand over receipt Effective as well as up to date with The latest information regarding the implementation Nursing hand over the patient in the room ICU/ICU. Expected educational institutions Nursing can develop Curriculum related abilities Managerial nursing who can Assist students in Improve good competence In applying manjerial roles Real nursing. This research can proceed with Explore more in the role Deep nursing manager Support the implementation of activities Nursing hand over the patient.

\section{Acknowledgements}

None.

\section{Conflict of interest}

The authors declare that there is no conflict of interest

\section{Reference}

1. Muninjaya AA, G Siregar, R Lawitono. Manajemen kesehatan. Jakarta: Penerbit Buku Kedokteran EGC; 2004

2. Freeman R, Gilbert R. Manajemen Jilid I. Alih Bahasa Alexander Sindoro. Jakarta: PT Prenhallindo; 1996.

3. Schlosser RW. The efficacy of augmentative and alternative communication: Toward evidence-based practice. San Diego: Academic Press; 2003.

4. Swansburg RC. Management and leadership for nurses manager. England: Jones and Barlett Publisher; 2000.

5. Alvarado K, Lee R, Christoffersen E, et al. Transfer of accountability: Transforming shift handover to enhance patient safety. Healthc $Q$. 2006;(9):75-79.

6. Rushton HC. Ethics of nursing shift report. AACN Adv Crit Care. 2010;21(4):38-384.

7. Potter PA, Perry AG. Fundamental keperawatan. Jakarta: EGC; 2006.

8. Sitorus R. Model praktik keperawatan professional di rumah sakit: penataan struktur dan proses (sistem) pemberian asuhan keperawatan di ruang rawat. Jakarta: EGC; 2006.

9. Triwibowo C. Manajemen pelayanan keperawatan di rumah sakit. Jakarta: Perpustakaan Nasional (KDT); 2013. 
10. Nursalam. Manajemen keperawatan aplikasi dan praktek keperawatan profesional. Jakarta: SalembaMedika; 2012.

11. Jefferson J. Communication SBAR module: Interpersona communication. United State: Jefferson Interprofessional Education Centre; 2012.

12. Smith E, Cronenwet L, Sherwood G. Current assassments of quality and safety education in nursing. Nurs Outlook. 2008;55(3):132-137.

13. Accreditation of Healthcare Organizations (JCAHO). National patient safety goals. 2013 .

14. Jefferson J. Communication SBAR module: Interpersona communication. United State: Jefferson Interprofessional Education Centre; 2012.

15. Hughes GR, Clancy MC. Working condition that support patient safety. Journal Nursing Care Quality. 2008;20(4):289-292.

16. Cahyono. Membangun budaya keselamatan pasien dalam praktek kedokteran. Yogyakarta: Kanisius;2008.

17. Arora V, Johnson J. A model for building a standardized hand-off protocol. Jt Comm J Qual Patient Saf. 2006;32(11):646-655.

18. Adams JM, Osborne MT. Advancing the evidence-base for a standardized provider handover structure: Staff nurse descriptions of information they need to deliver competent care. J Contin Educ Nurs. 2012;43(6):261-266.

19. Rab T. Agenda gawat darurat (critical care) jilid I, Edisi 2. Bandung: PT Alumni; 2007.

20. Reese DC. Occupation health and safety management: A practical approach. USA: Taylor and Francis Group; 2009.

21. Cohen MD, Hillagos P. Handoff in hospital: a review of the literature on information exchanged while transferring patient responsibility or control. USA.

22. Angood P. Why the joint comission cares about handoffs strategy. Reducing Risk During Handoffs. 2007;25(1):5-7.

23. Afiyanti Y, Rachmawati I. Metode penelitian kualitatif dalam riset keperawatan. Jakarta: Rajawali Pers; 2014

24. Anthon $\mathrm{H}$. Hubungan penerapan metode tim dengan kinerja perawa pelaksana di ruang rawat inap RSUD Kabupaten Majene. 2012

25. Bungin B. Penelitian kualitatif komunikasi, ekonomi, kebijakan publik, dan ilmu sosial lainnya. Jakarta: Prenada Media Group; 2011.

26. Charmaz K. Reconstructing grounded theory. In: Alasuutari P, Bickman L, editors. J Handbook of social research. London: Sage Publications; 2009

27. Corbin J, Strauss A. Basic of qualitative research: Techniques and procedures for developing grounded theory. California: Sage Publications; 2007.

28. Departemen Kesehatan Republik Indonesia. Instrumen evaluasi penerapan standar asuhan keperawatan di rumah sakit (cetakan keempat). Jakarta: Depkes; 2001.

29. Dewi M. Pengaruh pelatihan timbang terima pasien terhadap penerapan keselamatan pasien oleh perawat pelaksana di RSUD Raden Mattaher Jambi. Jurnal Health and Sport. 2012;5(3):646-655.

30. Fenton J, Wendy A. Developing a guide to improve the quality of nurses handover. Nurs Older People. 2006;18(11):32-36.

31. FJ. Patient safety and quality: An evidence-based handbook for nurses. Rockville: Agency for health care research and quality; 2008.
32. Gillies DA. Nursing management: A system approach. Philadelphia: WB Saunders Company; 2002

33. Howarth T, Hyde G. Developing and implementing new clinical communication practices: changing the nursing handover. Sydney: NSW Australia; 2008

34. Huber D. Leadership and nursing care management. Philadelphia: WB Saunders Company; 2006.

35. Jevon P, Ewens B. Monitoring the critically III patient. United Kingdom. 2012.

36. Kassesan, Jagoo. Managing change in the nursing handover from traditional to bed handover: A case study from Mauritius. BMC Nursing. 2012;6955:4-1.

37. Komisi Etik Penelitian Kesehatan (KEPK). Pedoman nasional etik penelitian kesehatan. Jakarta: Departemen Kesehatan; 2003.

38. Kuntoro A. Buku ajar manajemen keperawatan. Yogyakarta: Nuha Medika; 2010

39. Kurniadi A. Manajemen Keperawatan dan Perspektifnya. Jakarta: Badan Penerbit; 2013.

40. Kvale P. Family-centered approach improves communication and care in intensive care unit. 2011.

41. Manopo Q. Hubungan antara penerapan timbang terima pasien dengan keselamatan pasien oleh perawat pelaksana di RSU Gmim Kalooran Amurang. Jurnal Kesehatan Masyarakat. 2014;1(6):122-129.

42. Moleong IJ. Metodologi penelitian kualitatif (edisirevisi). Bandung Remaja Rosdakarya; 2005

43. NHS. Safe handover: Safe patients guidance on clinical handover for clinical and managers. United Kingdom: National Patient Safety Agency; 2012

44. Nolan J, Handley A, Soar J. European Resuscitation council guidelines for resuscitation 2005: section 4. Adult advanced life support. Resuscitation. 2005;67:181-189.

45. Nurachmah E. Asuhan keperawatan bermutu di rumah sakit. 2005.

46. Polit DF, Beck CT. Essentials of nursing research: Appraising evidence for nursing practice. Philadelphia: Wolters Kluwer Health, Lippincott Williams \& Wilkins; 2006

47. Poerwandari EK. Pendekatan kualitatif untuk penelitian perilaku manusia. Jakarta: Lembaga pengembangan sarana pengukuran dan pendidikan; 2005.

48. Pronovost $\mathrm{P}$, Berenholtz S, Dorman T, et al. Improving communication in the ICU using daily goals. Maryland: The Johns Hopkins University; 2003 .

49. Robins S, Coulter M. Manajemen Personalia dan SDM edisi kedelapan. Jakarta: Penerbit PT Indeks; 2007.

50. Saladien. Rancangan penelitian kualitatif. Modul penelitian kualitatif. Malang: Fakultas Ekonomi Universitas Brawijaya; 2006.

51. Schultz K, Carayon P, Hundt AS, et al. Care transitions in the out patient surgery preoperative process: Facilitators and obstacles to information flow and their concequences. Cognition, Technology \& Work. 2007;9(4):219-231

52. Scovell S. Role of the nurse- to-nurse handover in patient care. Nursing Standard. 2016;4(20):35-39.

53. Sexton A, Chan C, Elliott M, et al. Nursing handovers: do we really need them?. J Nurs Manag. 2004;12(1):37-42. 
54. Speziale HJS, Carpenter DR. Qualitative research in nursing: advancing the humanistic imperative. Philadelphia: Lippincot William Wilkins; 2007.

55. Suarli S, Bahtiar. Manajemen keperawatan dengan pendekatan praktik. Jakarta: Erlangga; 2009.

56. Sugiyono. Metode penelitian kuantitatif kualitatif \& RND. Bandung: Alfabeta; 2010.

57. Sumijatun. Manajemen keperawatan, konsep dasar dan aplikasi pengambilan keputusan klinis. Jakarta: Trans Info Media.

58. The Australian Council for Safety and Quality in Health Care. Clinical handover and patient safety. Sydney: Australian Resource Centre for Healthcare Innovation; 2005.
59. Trinkof AM, Geiger-Brown JM, Caruso CC, et al. Personal safety for nurse. Nursing Research. 2007;60(1):1-8.

60. Thomson B. Qualitative research: Grounded theory sample size and validity. 20011.

61. Wahyuni S. Managing Spill- over of control in alliances, under reviewed of international journal of management review. working paper management research centre UI. 2007.

62. WHO. Communications during patient hand-over. 2007.

63. William A, Manias E, Liew D. Interventions to reducing medicine errors in intensive care: a systematic review. $\mathrm{Br} J$ Clin Pharmacol. 2012;74(3):11-23. 